\title{
Mixed inheritance in the genetic control of ramulosis (Colletotrichum gossypii var. cephalosporioides) resistance in cotton
}

\author{
M.A.C. Oliveira ${ }^{1}$, J.B. Duarte ${ }^{2}$, C.L. Morello ${ }^{3}$, N.D. Suassuna ${ }^{3}$ and \\ A.B. Oliveira ${ }^{1}$ \\ ${ }^{1}$ Agência Goiana de Defesa Agropecuária, Itumbiara, GO, Brasil \\ ${ }^{2}$ Setor de Melhoramento de Plantas, Escola de Agronomia, \\ Universidade Federal de Goiás, Goiânia, GO, Brasil \\ ${ }^{3}$ Núcleo Cerrado, Embrapa Algodão, Santo Antônio de Goiás, GO, Brasil \\ Corresponding author: J.B. Duarte \\ E-mail: jbduarte.ufg@gmail.com
}

Genet. Mol. Res. 15 (3): gmr.15038667

Received March 29, 2016

Accepted May 5, 2016

Published September 2, 2016

DOI http://dx.doi.org/10.4238/gmr.15038667

Copyright (C 2016 The Authors. This is an open-access article distributed under the terms of the Creative Commons Attribution ShareAlike (CC BY-SA) 4.0 License

\begin{abstract}
Ramulosis is one of the most aggressive diseases in cotton, and understanding the genetic control of its resistance is imperative for selecting superior cotton genotypes in breeding programs. This study analyzed the inheritance pattern of this resistance using chi-square goodness-of-fit tests to determine the phenotypic proportions of the $\mathrm{F}_{2}$ generation, and a mixed inheritance approach to jointly model major gene and polygenes effects. $\mathrm{F}_{1}, \mathrm{~F}_{2}, \mathrm{Rc}_{1}$, and $\mathrm{Rc}_{2}$ generations were obtained by crossing resistant (BRS Facual, CNPA 2984, or CNPA 2043) and susceptible (Delta Opal, CNPA 999, or CNPA 2161) genotypes, and were assessed under field conditions with artificial inoculation of the pathogen (Colletotrichum gossypii var. cephalosporioides). Genetic control of the trait varied among the crossings. For Delta Opal x BRS
\end{abstract}


Facual and CNPA 2161 x BRS Facual, phenotypic segregations in the $\mathrm{F}_{2}$ generation did not differ from the expected proportions for the hypothesis of duplicate genes (15:1). For Delta Opal x CNPA 2043, the segregation did not differ from the expected proportions for dominant recessive epistasis (13:3). The hypothesis of genetic control by one major gene was supported only for the Delta Opal x CNPA 2043 crossing. Three other crossings showed evidence of polygenes in the inheritance of the trait. In conclusion, major genes and polygenes are likely involved in the genetic control of ramulosis resistance in cotton.

Key words: Gossypium hirsutum; Mixture models; Cotton over-budding; Ramulosis susceptibility

\section{INTRODUCTION}

In recent years, the Brazilian cotton industry has become increasingly important, establishing itself in the Cerrado region, mainly in the Mato Grosso, Bahia, and Goiás states, where the major cotton growing area is located. In the current crop season (2015/2016), the area is approximately 965.7 thousand hectares and the cotton production estimates are approximately 1.48 million tons of lint (CONAB, 2016a). Although the Brazilian cotton area decreased $17.2 \%$ in the last ten years, yield increased by approximately $45 \%$. This places Brazil as the largest producer of dryland cotton (CONAB, 2016b). Advances in genetics and production systems have a fundamental role in the industry's economic viability (Ferreira Filho \& Alves, 2007). However, this monoculture model leads to a systematic increase in the use of agricultural inputs, such as fungicides, in order to control the increasing incidences of diseases in the crop (Suassuna and Coutinho, 2011).

Cotton ramulosis is a disease caused by the fungus Colletotrichum gossypii var. cephalosporioides (A.S. Costa). In Brazil, it was observed for the first time in 1936, in São Paulo State (Costa and Fraga Jr, 1939). Currently, this pathogen is distributed across all Brazilian cotton-producing areas. The whole aerial part of the plant, mainly leaves, stems and bolls, may be infected at any stage of development, which can cause reduction in fiber production. C. gossypii var. cephalosporioides causes necrosis of the apical meristem, triggering development of lateral sprouts with over-budding that resemble witches'-brooms, and causing stunting. In those cases, boll production is dramatically reduced. An epidemic can occur when environmental conditions are favorable (e.g., an extended period of high humidity and considerable rainfall), and yield losses can exceed 80\%, depending on the cultivar (Lima et al., 1999; Cia et al., 2008). Ramulosis can be managed by using pathogen-free seeds, crop rotation, eliminating crop residues, chemical control (i.e., fungicides), and genetic resistance. Genetic resistance is undoubtedly the most effective tool in an integrated management program for this disease.

The breeding of herbaceous cotton (Gossypium hirsutum L. r. latifolium Hutch) with resistance to ramulosis has been limited, due to the lack of information about the genetic control of this resistance. Understanding the predominant gene action in the expression of a trait is crucial for directing the activities in a breeding program to obtain satisfactory genetic gains. Studies on the inheritance of this resistance have been conducted (Carvalho et al., 1988; Carvalho et al., 1994; Zandoná et al., 2006; Oliveira et al., 2010). However, there

Genetics and Molecular Research 15 (3): gmr.15038667 
is no consensus, especially regarding the number of genes involved and if the resistance is controlled by dominant or recessive alleles.

There have been independent estimations of the genetic parameters associated with the general effects of polygenes (minor effect genes) or major genes (Carvalho et al., 1988; Carvalho et al., 1994; Zandoná et al., 2006). However, when a trait has continuous distribution, it is important to assess if the inheritance is due to the action of major genes or if it is essentially polygenic. Mixture models or mixed inheritance models are used to jointly estimate the action of major genes and the effect of polygenes (Jiang et al., 1994; Bearzoti, 2004; Gonçalves et al., 2004; Rezende et al., 2004). When there is considerable environmental variation in relation to the individual effect of any gene, the effect of major genes may be mistaken for polygenic effects (Lynch and Walsh, 1998). Oliveira et al. (2010), in a quantitative genetic study (emphasis in polygenes) noted that resistance to ramulosis is predominantly oligogenic (from 1 to 21 genes), and the number of genes varied among different crossings due to differentiated fixation of alleles in the parents. Nevertheless, they also concluded that about $54 \%$ of the phenotypic variation was attributed to environmental variations. Therefore, it is justified to investigate the joint action of polygenes and major genes in the genetic control of this trait. We studied the genetic control of ramulosis resistance in cotton for different crossings, using conventional goodness of fit tests to determine phenotypic segregation in the $\mathrm{F}_{2}$ generation, and using mixed inheritance models to assess the joint action of major genes and polygenes.

\section{MATERIAL AND METHODS}

Hybridizations were carried out at the Agricultural Department of Goiás State experimental station (Seagro-GO) in Senador Canedo city, Brazil. The parental lines used in the crosses were selected from screenings for ramulosis that are regularly conducted in Embrapa cotton breeding program for the Brazilian savannah (Cerrado). Crossings were conducted between two groups of cotton experimental lines and commercial cultivars differing in the resistance level to ramulosis. The susceptible parents were the cultivar Delta Opal and experimental lines CNPA 999 and CNPA 2161. The group with the high level of disease resistance was composed of the BRS Facual cultivar and two experimental lines, CNPA 2984 and CNPA 2043. Nine crossings were performed between resistant and susceptible parents, but CNPA 2161 x CNPA 2043 was discarded because the parents did not show means with significant difference for disease severity $(\alpha=0.05)$. Subsequently, one $F_{1}$ boll was harvested from each crossing and the harvested seeds were sown for self-fertilization and to obtain $F_{2}$ individuals. During the same season, there were backcrosses to obtain $\mathrm{Rc}_{1}$ and $\mathrm{Rc}_{2}$ generations. Thus, 42 treatments (generations $\mathrm{F}_{1}, \mathrm{~F}_{2}, \mathrm{Rc}_{1}$, and $\mathrm{Rc}_{2}$ for each crossing, plus the six parents) were assessed for disease severity in a field experiment conducted in Santa Helena County $\left(50.6^{\circ} \mathrm{W}, 17.8^{\circ} \mathrm{S}\right.$, and $485 \mathrm{~m}$ in altitude). The total rainfall over the experiment was $1176 \mathrm{~mm}$, and an average daily insolation of $3.98 \mathrm{~h}$.

The experimental design was a randomized complete block with three replications. Sowing was carried out on December 28, 2007. Plots with two rows (5.0 m long) of plants were used for the parents and the $\mathrm{F}_{1}, \mathrm{Rc}_{1}$, and $\mathrm{Rc}_{2}$ generations; four rows $(5.0 \mathrm{~m})$ were used for the $\mathrm{F}_{2}$ generation. The spacing between rows was $0.9 \mathrm{~m}$, with a sowing density of 9 plants $/ \mathrm{m}$.

Pathogen isolates were sampled from cotton growing areas in counties across the westcentral region of Brazil. Leaf fragments with ramulosis lesions were surface sterilized for $60 \mathrm{~s}$

Genetics and Molecular Research 15 (3): gmr.15038667 
with sodium hypochlorite ( $\mathrm{NaClO} 1.5 \%$ ), rinsed for $30 \mathrm{~s}$ in sterilized distilled water immersed in alcohol (70\%), and washed again in sterile distilled water (SDW). The fragments, each with a single lesion, were placed on sterile filter paper to remove excess water and transferred to potato dextrose agar (PDA) medium (9-cm diameter Petri dishes) with lactic acid (1\%). Koch's postulates were fulfilled by pathogenicity tests using cotton cultivar CNPA ITA-90. Cotton plants were artificially inoculated by spraying a spore suspension $\left(5 \times 10^{4}\right.$ conidia/ $\mathrm{mL}$ ) until runoff. Five weekly inoculations were performed to ensure widespread deposition of the spores. The inoculum suspension was prepared with three isolates of $C$. gossypii var. cephalosporioides, from Acreúna (cv. CNPA 0095) and Santa Helena (cv. CNPA 0104) in Goiás State, and Campo Verde (cv. CNPA 0116) in Mato Grosso State. The isolates were grown on PDA medium on Petri dishes. The dishes were kept at $25^{\circ} \mathrm{C}$, with a $12 \mathrm{~h}$ photoperiod. After ten days, $10 \mathrm{~mL}$ of SDW were added to each dish, and spores were removed by gently brushing to obtain the spore suspension.

The assessment of the disease severity (April 13, 2008) was performed for all plants in the plots (10,720 observations). The following disease severity scale, proposed by Suassuna et al. (2008), was used: $1=$ no symptoms; $2=$ necrotic lesions on young leaves; $3=$ lesions on the leaves, internode shortening, and early emission of lateral sprouts (up to three new sprouts); $4=$ lesions on the leaves, internode shortening, emission of lateral sprouts (in general, three to ten sprouts), and low vegetative development; and $5=$ lesions on the leaves, excessive sprouting (over ten sprouts), internode shortening, and plant stunting (dwarfism).

Based on results of Oliveira et al. (2010), different hypotheses of phenotypic segregation in the $\mathrm{F}_{2}$ generation were tested, but it was assumed that only one or two genes are involved in the inheritance of the trait. For these tests, two other crossings (Delta Opal x CNPA 2984 and CNPA 999 x BRS Facual) were discarded, because, based on the previous study, the estimated number of genes involved in the inheritance of the trait were greater than two (14 and 21 genes, respectively). Departures from the proportions 3:1 (one major gene) and 9:3:3:1 (two independent major genes) were calculated and statistically tested.

We first assumed segregation in only two phenotypic classes, and therefore the disease grades 1, 2, and 3 were assembled in the class of resistant plants (R), and grades 4 and 5 in the class of susceptible plants (S). It was then possible to test the hypotheses: i) allelic interaction with complete dominance of the resistance allele $(\mathrm{R})$ on the allele of susceptibility, considering monogenic inheritance (3R:1S); ii) gene interaction of double recessive epistasis (9R:7S); iii) dominant recessive epistasis (13R:3S); and iv) duplicate genes without dominant interaction (15R:1S). Secondly, we assumed segregation in three phenotypic classes, and therefore considered the plants with grades 1 and 2 as resistant, with grade 3 as moderately resistant, and those with grades 4 and 5 as susceptible. In this case, the tested hypotheses were: i) allele interactions of incomplete dominance and/or with overdominance (1R:2MR:1S); ii) gene interactions with recessive epistasis (9R:3MR:4S); iii) dominant epistasis (12R:3MR:1S); and iv) duplicate genes with dominant interaction (9R:6MR:1S). For all hypotheses, statistical significance was measured using the chi-square $\left(\mathrm{c}^{2}\right)$ goodness-of-fit test at a $5 \%$ level of probability.

To assess the joint action of major genes and polygenes controlling the trait, the approach of distributional mixtures or mixed inheritance models was used, as proposed by Jiang et al. (1994) and adapted by Silva (2003). This method assumes that under normality there is a single probability density function in each of the $\mathrm{P}_{1}, \mathrm{P}_{2}$, and $\mathrm{F}_{1}$ generations, while in generations $\mathrm{F}_{2}, \mathrm{Rc}_{1}$, and $\mathrm{Rc}_{2}$ we find mixtures of normal distributions, with proportions set by 
the expected frequency of genotypes resulting from major gene segregation in each generation (Bearzoti, 2004). Therefore, by considering each model for the probability distribution of the data (Table 1), it was possible to perform tests that assessed different inheritance hypotheses. This involved likelihood fitting of hierarchical models, which were compared by the likelihood ratio (LR) test:

$$
L R=-2 \ln \frac{L\left(M_{i}\right)}{L\left(M_{j}\right)}
$$

where $L\left(M_{i}\right)$ and $L\left(M_{j}\right)$ are the likelihoods of the models $i$ and $j$, with model $i$ nested to the model $\mathrm{j}$. Under normal probability distribution, the LR statistic has asymptotic chi-square distribution, with degrees of freedom given by the difference between the numbers of parameters in models $i$ and $j$ (Mood et al., 1974).

Table 1. Genetic models and their parameters for evaluation of mixed inheritance, determined by major gene and polygenes, separately or simultaneously, from generation data obtained from controlled crossings (adapted from Silva, 2003).

\begin{tabular}{l|l|l|l|l}
\hline Model & Inheritance & Greater gene & Polygenes & Parameters \\
\hline 1 & Major gene + Polygenes & Additive and dominance & Additive and dominance & $\mu, \mathrm{A}, \mathrm{D},[\mathrm{a}],[\mathrm{d}], \mathrm{V}_{\mathrm{A}}, \mathrm{V}_{\mathrm{D}}, \mathrm{S}_{\mathrm{AD}}, \sigma^{2}$ \\
\hline 2 & Major gene + Polygenes & Additive and dominance & Additive & $\mu, \mathrm{A}, \mathrm{D},[\mathrm{a}], \mathrm{V}_{\mathrm{A}}, \sigma^{2}$ \\
\hline 3 & Major gene + Polygenes & Additive & Additive and dominance & $\mu, \mathrm{A},[\mathrm{a}],[\mathrm{d}], \mathrm{V}_{\mathrm{A}}, \mathrm{V}_{\mathrm{D}}, \mathrm{S}_{\mathrm{AD}}, \sigma^{2}$ \\
\hline 4 & Major gene + Polygenes & Additive & Additive & $\mu, \mathrm{A},[\mathrm{a}], \mathrm{V}_{\mathrm{A}}, \sigma^{2}$ \\
\hline 5 & Polygenes & - & Additive and dominance & $\mu,[\mathrm{a}],[\mathrm{d}], \mathrm{V}_{\mathrm{A}}, \mathrm{V}_{\mathrm{D}}, \mathrm{S}_{\mathrm{AD}}, \sigma^{2}$ \\
\hline 6 & Polygenes & Additive and dominance & & $\mu,[\mathrm{a}], \mathrm{V}_{\mathrm{A},}, \sigma^{2}$ \\
\hline 7 & Major gene & Additive & - & $\mu, \mathrm{A}, \mathrm{D}, \sigma^{2}$ \\
\hline 8 & Major gene & \multicolumn{1}{c}{-} & - & $\mu, \mathrm{A}, \sigma^{2}$ \\
\hline 9 & None & \multicolumn{1}{c}{-} & $\mu, \sigma^{2}$ \\
\hline
\end{tabular}

$\mu=$ constant of reference; $\mathrm{A}=$ additive effect of major gene; $\mathrm{D}=$ dominance effect of major gene; $[\mathrm{a}]=$ additive effect of polygenes; [d] = dominance effect of polygenes; $V_{A}=$ additive variance of polygenes; $V_{D}=$ dominance variance of polygenes; $\mathrm{S}_{\mathrm{AD}}$ = products sum of dominant and additive effects; $\mathrm{s}^{2}=$ environmental variance.

Using this approach, a more general model was considered the one that describes genetic control as resulting from the action of one major gene plus polygenes, with its additive and dominant effects, under common environmental variance (homoscedasticity). This corresponds to Model 1, with nine parameters (Table 1). For different pairs of hierarchical models (i.e., complete model, $\mathrm{j}$; and reduced model, $i$ ), the pairs 1 vs 5 , and 1 vs 7 were contrasted first. The LR statistics associated with these contrasts allows us to test the hypothesis of genetic control determined solely by major gene, with 2 d.f. (degrees of freedom), and the hypothesis of genetic control determined solely by polygenes ( 5 d.f.), respectively. Pairs of the models 7 vs 8 and 5 vs 6 were also contrasted to assess the dominance effects of the major gene and the polygenes, respectively. The Monogen v. 1 software, developed by Silva (2003), was used for these analyses.

\section{RESULTS AND DISCUSSION}

The results of this study are outlined according two approaches. We first analyzed the results from the goodness-of-fit tests $\left(\chi^{2}\right)$ applied to hypotheses concerning the inheritance 
governed by only one or two pairs of genes (Table 2). After, in view of evidences against such hypotheses for some crossings, we conducted LR tests to assess the simultaneous effects of major gene and polygenes, using the mixed inheritance model approach (Table 3).

Table 2. Chi-square goodness-of-fit test for theoretical ratios of phenotypic segregation in the $\mathrm{F}_{2}$ generation, based on cotton ramulosis severity grades for crossings between contrasting parents and in the assumption that only one or two genes are involved in the inheritance of the trait.

\begin{tabular}{|c|c|c|c|c|c|c|c|c|}
\hline \multirow{2}{*}{ Crossings } & \multicolumn{8}{|c|}{ Theoretical ratios } \\
\hline & $3: 1$ & $1: 2: 1$ & $9: 7$ & $9: 3: 4$ & $12: 3: 1$ & $13: 3$ & $15: 1$ & $9: 6: 1$ \\
\hline Delta Opal x BRS Facual & $* *$ & ** & ** & $* *$ & ns & $* *$ & ns & ** \\
\hline Delta Opal x CNPA 2043 & ** & ** & ** & $* *$ & *** & ns & $* *$ & ** \\
\hline CNPA 999 x CNPA 2043 & ** & ** & ** & $* *$ & ** & $* *$ & ** & $* *$ \\
\hline CNPA 999 x CNPA 2984 & ** & ** & ** & $* *$ & ** & $* *$ & * & ** \\
\hline CNPA 2161 x BRS Facual & $* *$ & $* *$ & $* *$ & $* *$ & $* *$ & $* *$ & ns & $* *$ \\
\hline CNPA 999 x CNPA 2984 & ** & $* *$ & $* *$ & $* *$ & $* *$ & $* *$ & $*$ & $* *$ \\
\hline
\end{tabular}

*,**Significant values at 5 and $1 \%$ probability, respectively; $n s=$ not significant values at $5 \%$ probability.

Table 3. Chi-square $\left(\chi^{2}\right)$ estimates and probabilities of significance (P values) for likelihood ratio tests of contrasting hypotheses of nested mixed inheritance models for ramulosis resistance in cotton.

\begin{tabular}{|c|c|c|c|c|}
\hline \multirow[t]{2}{*}{ Contrast of models ${ }^{1}$} & \multicolumn{2}{|c|}{ Delta Opal x BRS Facual } & \multicolumn{2}{|c|}{ Delta Opal x CNPA-2043 } \\
\hline & $\chi^{2}$ & $P$ value & $\chi^{2}$ & $P$ value \\
\hline 1 vs 5 & 3.20 & 0.20 & 41.65 & $<0.0001$ \\
\hline $1 v s 7$ & 0.18 & 0.99 & 12.08 & 0.033 \\
\hline 7 vs 8 & 18.44 & $<0.0001$ & 175.19 & $<0.0001$ \\
\hline 5 vs 6 & 11.27 & 0.01 & 11.27 & $<0.0001$ \\
\hline \multirow[t]{2}{*}{ Contrast of models } & \multicolumn{2}{|c|}{ Delta Opal x CNPA-2984 } & \multicolumn{2}{|c|}{ CNPA-999 x BRS Facual } \\
\hline & $\chi^{2}$ & $P$ value & $\chi^{2}$ & P value \\
\hline 1 vs 5 & 5.03 & 0.08 & - & - \\
\hline 1 vs 7 & 1.51 & 0.91 & - & - \\
\hline 7 vs 8 & 24.82 & $<0.0001$ & $\mathrm{nv}^{2}$ & - \\
\hline 5 vs 6 & 18.07 & 0.0004 & 9.64 & 0.02 \\
\hline \multirow[t]{2}{*}{ Contrast of models } & \multicolumn{2}{|c|}{ CNPA-999 $\times$ CNPA-2043 } & \multicolumn{2}{|c|}{ CNPA-999 x CNPA-2984 } \\
\hline & $\chi^{2}$ & $P$ value & $\chi^{2}$ & $P$ value \\
\hline 1 vs 5 & $\mathrm{nv}$ & - & nv & - \\
\hline 1 vs 7 & 16.75 & 0.0052 & 11.27 & 0.05 \\
\hline $7 v s 8$ & 42.17 & $<0.0001$ & 50.01 & $<0.0001$ \\
\hline $5 v s 6$ & 59.05 & $<0.0001$ & 64.26 & $<0.0001$ \\
\hline \multirow[t]{2}{*}{ Contrast of models } & \multicolumn{2}{|c|}{ CNPA-2161 x BRS Facual } & \multicolumn{2}{|c|}{ CNPA-2161 x CNPA-2984 } \\
\hline & $\chi^{2}$ & $P$ value & $\chi^{2}$ & P value \\
\hline 1 vs 5 & $\mathrm{nv}$ & - & - & - \\
\hline $1 v s 7$ & 0.64 & 0.98 & - & - \\
\hline 7 vs 8 & 7.13 & 0.076 & nv & - \\
\hline 5 vs 6 & 7.85 & 0.049 & 9.64 & 0.022 \\
\hline
\end{tabular}

${ }^{1}$ Tested hypotheses: 1 vs $5=$ major gene effect ( 2 d.f.); 1 vs $7=$ polygenes effects $(5$ d.f. $) ; 7$ vs $8=$ dominance of major gene ( 1 d.f.); 5 vs $6=$ dominance of polygenes ( 3 d.f.). ${ }^{2} \mathrm{nv}=$ negative values from convergence problems in calculation of likelihood functions.

Goodness-of-fit tests allowed assessment of the departures of the $\mathrm{F}_{2}$ segregation from the Mendelian proportions traditionally expected, and the prevalent gene or allelic interactions. The hypotheses of monogenic inheritance with complete or incomplete dominance could not be accepted in any of the crossings assessed, because the phenotypic segregation observed in $\mathrm{F}_{2}$ did not adjust to proportions 3R:1S or 1R:2MR:1R (Table 2). On the other hand, Carvalho et al. (1988) found frequencies that adjusted to segregation $3 \mathrm{~S}: 1 \mathrm{R}$ in the $\mathrm{F}_{2}$ population from 
the HR 21 T-16-RR x SU 0450-8909 crossing. They concluded that inheritance of this trait is monogenic, with partial dominance for the susceptibility. The disagreement of these results can be due to the different crossings used in each study, involving parents with differentiated fixation of alleles. In a certain crossing the parents can share a single non-fixed locus, while in other crossing the parents can share a greater number of these loci. This can be explains the differences in the number of genes controlling the trait when different crossings are used.

For this same pathosystem, Oliveira et al. (2010) also estimated the number of genes involved in the inheritance of the trait. The authors used quantitative genetics based on means and variance components of generations, and they noted the participation of only one major gene for the crossings Delta Opal x CNPA 2043, CNPA 999 x CNPA 2043, CNPA 999 x CNPA 2984, CNPA 2161 x BRS Facual, and CNPA 2161 x CNPA 2984. However, in the crossings Delta Opal x BRS Facual, CNPA 999 x BRS Facual, and Delta Opal x CNPA 2984, two genes, 14 genes, and 21 genes were identified, respectively. Thus, caution was recommended when interpreting results from different crossings, and also because there is considerable environmental influence on the phenotypic expression of the trait.

For the expression of complex traits like ramulosis resistance in cotton, there are likely combined actions of different genes in addition to allelic interactions. If we assume, for example, that only two genes are controlling the trait, independent distribution would be expected when they are on different chromosomes, which would result in proportions according to Mendel's 2nd law (9:3:3:1). However, if the independence condition is not assured, other gene interactions and ratios could be observed in the $F_{2}$ generation, for example, 12:3:1, 9:6:1, 9:7, 9:3:4, 15:1, and 13:3 (Ramalho et al., 2004).

Based on these assumptions, the gene interaction of the dominant epistasis type (12R:3MR:1S) cannot be statistically rejected by the $\mathrm{c}^{2}$ test $(\mathrm{P}>0.05)$ for the Delta Opal $\mathrm{x}$ BRS Facual crossing (Table 2). This result indicates the possible participation of two genes, each one with two alleles and independent distribution, in which the dominant allele (A) in one of the locos is responsible for the moderately resistant (MR) phenotype, while the recessive allele (a) does not produce any transcript that results in resistance to the plant, which manifests as susceptibility (S) in homozygous. In the other locus, an epistatic and dominant allele (B) prevents the expression of the alleles $A$ and $a$, and the plant is resistant $(\mathrm{R})$. Hence, the expected result in the $\mathrm{F}_{2}$ generation is the ratio: $12 \mathrm{R}\left(9 \mathrm{~A} \_\mathrm{B} \_+3 \mathrm{aaB}\right.$ ) $: 3 \mathrm{MR}\left(\mathrm{A} \_b b\right): 1 \mathrm{~S}(\mathrm{aabb})$.

In the Delta Opal x CNPA-2043 crossing, the recessive and dominant epistasis (13R:3S) is the hypothesis that could not be statistically rejected (Table 2). In this case, there is participation of two genes with two alleles each, in which resistance is conditioned by genotypes A_B_, A_bb, and aabb $(9+3+1)$, and susceptibility by the genotype aaB_ (3). This occurs because the allele $\mathrm{A}$ is epistatic and dominant, while $\mathrm{b}$ is epistatic and recessive, with A inhibiting B.

Other types of gene interactions do not necessarily imply the inhibition of metabolic pathways, conversions, or structural changes in the plants. One of the best-known examples is the segregation determined by duplicated genes (Ramalho et al., 2004). In this case, genes with identical functions can be represented more than once in the genome, and this changes the expected Mendelian ratios. For example, if two genes, A and B, are copies of the same gene, the expected ratio is $15 \mathrm{R}\left(9 \mathrm{~A} \_\mathrm{B} \_+3 \mathrm{~A} \_b \mathrm{~b}+1 \mathrm{aaB}\right)$ ) $1 \mathrm{~S}(\mathrm{aabb})$. This hypothesis was not rejected $(\mathrm{P}>0.05)$ for two of the crossings assessed, Delta Opal x BRS Facual and CNPA 2161 $\mathrm{x}$ BRS Facual (Table 2). Therefore, in some cases, this type of genetic control could explain

Genetics and Molecular Research 15 (3): gmr.15038667 
the inheritance of this trait. This proportion was also reported in the ramulosis resistance study conducted by Zandoná et al. (2006) for $\mathrm{F}_{2}$ genotypes from an IAC 23 x Stoneville 474 crossing.

Our study used, for the first time, the mixed inheritance model approach to evaluate the simultaneous involvement of a major gene and polygenes in ramulosis resistance control in cotton. Firstly we evaluated the hypothesis of genetic control determined by just one major gene with a dominance effect. For this, we take account the following contrasts between pairs of models: 1 vs 5 or $7 v s$. For both contrasts this hypothesis can only be accepted $(\mathrm{P}<0.05)$ for the Delta Opal x CNPA 2043 crossing (Table 3). This corroborates the results noted by Oliveira et al. (2010) for this same crossing, including the dominance effect of increasing the resistance to the disease; however, it does not confirm the chi-square goodness of fit test for the 3:1 ratio in the $F_{2}$ generation (Table 2). The other crossings were not consistent for both contrasts, either because of the non-significance of the statistical test $(\mathrm{P}>0.05)$ or because of difficulties in determining the statistics (e.g., negative values or convergence problems). According to Rezende et al. (2004), these problems are intrinsic to this method of analysis and occur when the iteration algorithm cannot find parametric values that maximize the likelihood function. Hence, the combined use of this approach with other methods may be necessary.

The contrast between models 1 and 7 was used to verify the null hypothesis related to the exclusive effects of polygenes. Thus, a significant result $(\mathrm{P}<0.05)$ was observed for the crossings CNPA 999 x CNPA 2043, Delta Opal x CNPA 2043, and CNPA 999 x CNPA 2984 (Table 3). Therefore, for at least half of the crossings tested, it is possible that polygenes are involved in the inheritance of ramulosis resistance in cotton. Furthermore, the contrast between models 5 and 6 tested the presence of polygene dominance, and the results revealed that such effects are also involved in genetic control of the trait for these crossings.

The involvement of polygenes, as identified in this study using mixed inheritance models, can explain the several major genes identified by Oliveira et al. (2010) in some crossings (e.g., CNPA 999 x BRS Facual, with 14 genes; and Delta Opal x CNPA 2984, with 21 genes). Overall, our study highlights the importance of adopting different methodological approaches for investigating genetic control for complex traits, such as ramulosis resistance in cotton. This is even more important when the trait is not very contrasting between parents. Furthermore, in these studies it is recommended the use of molecular markers to further reduce the possibility of interpretative mistakes arising because of possible biases associated with the different approaches.

\section{Conflicts of interest}

The authors declare no conflict of interest.

\section{ACKNOWLEDGMENTS}

The authors thank Fundo de Incentivo à Cultura do Algodão (Fialgo) for partially funding this research.

\section{REFERENCES}

Bearzoti E (2004). Modelos de herança genética combinando efeitos poligênicos e de genes maiores. In: Anais do $8^{\circ}$

Simpósio de Atualização em Genética e Melhoramento de Plantas, Lavras, 44-53.

Genetics and Molecular Research 15 (3): gmr.15038667 
Carvalho LP, Lima EF, Carvalho JMFC and Moreira JAN (1988). Herança da resistência à ramulose do algodoeiro (Colletotrichum gossypii var. cephalosporioides). Fitopatol. Bras. 13: 10-15.

Carvalho LP, Cruz CD, Morais CF and Lima EF (1994). Hereditariedade da resistência do algodoeiro à ramulose causada por Colletotrichum gossypii South var. cephalosporioides A.S. Costa. Rev. Ceres 41: 254-262.

Cia E, Fuzatto MG, Kondo JI, Lüders RR, et al. (2008). Reação de cultivares e linhagens de algodoeiro às principais doenças que ocorrem em regiões produtoras do Brasil. Rev. Ceres 55: 518-524.

CONAB (Companhia Nacional de Abastecimento) (2016a). Acompanhamento da safra brasileira de grãos: sétimo levantamento 2015/2016. CONAB, Brasília. http://www.conab.gov.br/OlalaCMS/uploads/ arquivos/16_04_07_10_39_11_boletim_graos_abril_2016.pdf. Accessed April 10, 2016.

CONAB (Companhia Nacional de Abastecimento) (2016b). Séries históricas: algodão. CONAB, Brasília. http://www. conab.gov.br/conteudos.php?a=1252\&t=. Accessed April 10, 2016.

Costa AS and Fraga Jr CG (1939). Sôbre a natureza da "ramulose" ou "superbrotamento" do algodoeiro. J. de Agronomia 2: $151-160$.

Ferreira Filho JBS and Alves LRA (2007). Aspectos econômicos do algodão no cerrado. In: Algodão no Cerrado do Brasil (Freire EC, eds.). 1st edn. Ass. Bras. Prod. Algodão, Brasília, 53-89.

Gonçalves RP, Bearzoti E and Ferreira DF (2004). Avaliação da razão de verossimilhança generalizada em testes de hipóteses sobre o controle genético de características contínuas. Semina: C. Agr. 25: 281-292 10.5433/1679-0359.2004v25n $4 \mathrm{p} 281$.

Jiang C, Pan X and Gu M (1994). The use of mixture models to detect effects of major genes on quantitative characters in a plant breeding experiment. Genetics 136: 383-394.

Lima EF, Batista FAZ and Vieira RM (1999). Principais doenças do algodoeiro e seu controle. In: O agronégocio do algodão no Brasil (Beltrão NEM, ed.). 1st edn. Embrapa Comun. Transf. Tecnol., Brasília, 717-752.

Lynch M and Walsh B (1998). Genetics and analysis of quantitative traits. Sinauer Associates, Sunderland.

Mood AM, Grabill FA and Boes DC (1974). Introduction to the theory of statistics. 3rd edn. McGraw-Hill Kogakusha, Tokyo.

Oliveira MAC, Duarte JB, Morello CL, Suassuna ND, et al. (2010). Inheritance of resistance to Colletotrichum gossypii var. cephalosporioides in cotton. Crop Breed. Appl. Biotechnol. 10: 65-73 http://dx.doi.org/10.12702/1984-7033. v10n01a09.

Ramalho MAP, Santos JB and Pinto CABP (2004). Genética na agropecuária. 3rd edn. Editora UFLA, Lavras.

Rezende VF, Vencovsky R, Cárdenas FEN, Silva HPS, et al. (2004). Mixed inheritance model for resistance to anthracnose leaf blight in maize. Crop Breed. Appl. Biotechnol. 4: 115-122. http://dx.doi.org/10.12702/1984-7033.v04n01a19

Silva WP (2003). Estimadores de máxima verossimilhança em mistura de densidades normais: uma aplicação em genética. Master's thesis, UFLA, Lavras.

Suassuna ND and Coutinho WM (2011). Manejo das principais doenças do algodoeiro no cerrado Brasileiro. In: Algodão no cerrado do Brasil (Freire EC, ed.). 2nd edn. ABRAPA, Brasília, 567-612.

Suassuna ND, Coutinho WM and Morello CL (2008). Resistência genética do algodoeiro a doenças. In: O agronégocio do algodão no Brasil (Beltrão NEM, Azevedo DMP, eds.). 2nd edn. Embrapa Inf. Tecnol., Brasília, 327-354.

Zandoná C, Novaes TG, Mehta YR, Schuster I, et al. (2006). Herança de resistência a Colletotrichum gossypii var. cephalosporioides em algodoeiro brasileiro. Fitopatol. Bras. 31: 76-78 http://dx.doi.org/10.1590/S0100$\underline{41582006000100013 .}$.

Genetics and Molecular Research 15 (3): gmr.15038667 